\title{
Effect of Nutrient Omission on Grain Yield and Yield Components of Maize (Zea mays L.) at Kersa District, Jimma Zone, Southwestern Ethiopia
}

\author{
Obsa Atnafu ${ }^{1, *}$, Tesfaye Balemi ${ }^{2}$, Alemayehu Regassa ${ }^{3}$ \\ ${ }^{1}$ Jimma Agricultural Research Center, Jimma, Ethiopia \\ ${ }^{2}$ Debre Zeit Agricultural Research Center, Debre Zeit, Ethiopia \\ ${ }^{3}$ Department of Natural Resource Management, Jimma University, Jimma, Ethiopia
}

Email address:

obsaatnafu@gmail.com (O. Atnafu),t.balemi20015@gmail.com (T. Balemi), alemrega@yahoo.com (A. Regassa)

${ }^{*}$ Corresponding author

\section{To cite this article:}

Obsa Atnafu, Tesfaye Balemi, Alemayehu Regassa. Effect of Nutrient Omission on Grain Yield and Yield Components of Maize (Zea mays L.) at Kersa District, Jimma Zone, Southwestern Ethiopia. Agriculture, Forestry and Fisheries. Vol. 10, No. 1, 2021, pp. 7-15. doi: $10.11648 /$ j.aff.20211001.12

Received: September 30, 2020; Accepted: October 21, 2020; Published: March 10, 2021

\begin{abstract}
Application of fertilizer is the most effective means to increase nutrient uptake in crop plants and improve yields and quality. A field experiment was conducted with an objective to identify which of macronutrients $\mathrm{N}, \mathrm{P}$ and $\mathrm{K}$ are limiting maize grain and yield components in the study area during 2017/18 cropping season. The experiment was laid out in a completely randomized block design with six treatments replicated across six farmers' fields in Kersa district, Jimma zone, south western Ethiopia. The trial consisted of six treatments, unfertilized control, PK, NK, NP, NPK and NPK+. Maize grain yield was the highest for the NPK treatment followed by NPK+ treatment but lowest for the unfertilized control and N omitted plots. In absence of N, P, and K maize grain yields were significantly lower compared to that of NPK and NPK + treatments. Among the different treatments, NPK gave the highest grain yield $\left(9185 \mathrm{~kg} \mathrm{ha}^{-1}\right)$, while the control treatment gave the lowest grain yield $\left(1861.3 \mathrm{~kg} \mathrm{ha}^{-1}\right)$. Grain yield levels obtained for different fertilizer treatments were ranked as $\mathrm{NPK}>\mathrm{NPK}+>\mathrm{NP}>\mathrm{PK}>\mathrm{NK}$, illustrating that $\mathrm{N}$ deficiency was the most yield limiting nutrient followed by P and K in order. Therefore, NPK is the most suitable balanced fertilizers as application of secondary and micronutrients did not further enhance grain yield in the study area.
\end{abstract}

Keywords: Maize, Nutrient, Nitrogen, Phosphorus, Potassium

\section{Introduction}

Most soils cannot supply all essential plant nutrients in sufficient amounts to support good crop growth and yield and hence the application of fertilizer is one of the most effective means to increase nutrient uptake in crop plants and improve crop yields and quality [1]. Low soil fertility is a major factor implicated for the generally low crop yields in most agroecological regions of the world [2]. Minerals are necessary for the maintenance of certain physicochemical processes and are essential for plants. These inorganic substances are used by plants in many ways. Macronutrients play a key role in plant growth and development and are incorporated into the structure of plants. Crop productivity is affected by the type as well as amount of fertilizer applied to the plants.
Mineral fertilizers are the major nutrient sources to supply sufficient nutrients in soil as well as to promote better plant productivity.

Low soil fertility status of agricultural land of smallholders is mentioned as one of the main constraints of crop yields in Ethiopia. In addition to the low soil fertility status of Ethiopian soils, partly due to the removal of nutrients through harvested products and losses through erosion and leaching, phosphorus fixation and aluminum toxicity are two major constraints of most Ethiopian soils [3]. This is particularly apparent in soils with $\mathrm{pH}$ less than 5.5, the effect being attributed mainly to nutrient deficiency and toxicity. In such soils, phosphate is unavailable to plant roots because of fixation unless it is applied in large amounts [4]. Many empirical studies $[5,6]$ have documented the problem of low 
soil nutrient reserves and negative nutrient balances in croplands with few or no external nutrient inputs compared to the nutrient status of forest areas, grazing or well managed lands. Maize is a high nutrient-demanding crop, requiring the intensive application of inorganic or organic fertilizers to produce a high yield [7]. Fertilizers are needed to replenish the nutrients that are removed from the soil when plants are collected and to supplement the soil with more nutrients to increase production [8].

Nitrogen $(\mathrm{N})$, phosphorus $(\mathrm{P})$ and potassium $(\mathrm{K})$ are macronutrients that play a major role in plant growth and crop yields [4]. In smallholder farming systems in sub-Sahara Africa (SSA), removal of N, P and $\mathrm{K}$ from fields through crop harvest and farms often exceeds input via applied fertilizers. Ethiopia is considered as one of the most vulnerable countries in SSA with regard to soil fertility depletion because of its mountainous topography and intensive farming systems based on small cereals. Indeed, the soils in Ethiopia are being depleted at annual rates of 41 $\mathrm{kg} / \mathrm{ha}$ for N, $6 \mathrm{~kg} / \mathrm{ha}$ for $\mathrm{P}$, and $26 \mathrm{~kg} / \mathrm{ha}$ for $\mathrm{K}$ [9]. Such negative $\mathrm{N}, \mathrm{P}, \mathrm{K}$ balance sheets lead to a gradual and insurmountable decrease in N, P and $\mathrm{K}$ soil fertility status [10]. Restoration of soil fertility status and the provision of crop specific $\mathrm{N}, \mathrm{P}$ and $\mathrm{K}$ recommendations are prerequisites to increase crop yields.

The major problems of maize production in southwestern Ethiopia are infertile soils with high soil acidity and low available phosphorus content. Maize grain yields are variable across farmers' fields. This is due to variability in soil conditions, management practices and crop response to nutrients. Chemical fertilizers play a significant role in yield increment however, the application of higher amount of fertilizers do not always result in increased maize yield [11]. Nutrient limitation in soils has led to a drastic decline in maize yields in most smallholder farms. This is caused by decline in soil fertility $[12,13]$, which inevitably leads to low agricultural productivity. It is evident that agricultural output is fundamentally affected by productivity status of soil. This decline in soil fertility has decreased farmland productivity in most smallholder farming communities [14]. The existing fertilizer recommendation is based on blanket recommendation which assumes that the need of a crop for nutrients is constant over time and large areas. Research that aims to improve soil fertility management and productivity of small-scale farmers has to reckon with soil variation by identifying the most limiting nutrient elements and come up with flexible recommendations rather than blanket recommendations [15]. Moreover, the need for supplemental nutrients vary greatly among fields, seasons and years and a blanket dose of fertilizer will not fit to all fields. There is a need to investigate crop response to nutrient application to know the most yield limiting nutrients in smallholder fields of Ethiopia. Therefore, the objectives of this study were to identify the most yield limiting nutrient in maize and to quantify the magnitude of yield limitation due to different nutrient omission namely: $\mathrm{N}, \mathrm{P}, \mathrm{K}$ and secondary and micronutrients in the study area.

\section{Materials and Methods}

\subsection{Description of the Study Area}

The study was conducted in Kersa district, Jimma Zone, Oromia National Regional State, Southwestern Ethiopia. Kersa is one of the districts in Jimma Zone of Oromia Region. Geographically, the district is located between $7^{\circ} 35^{\prime}-8^{\circ} 00^{\prime} \mathrm{N}$ latitudes, $36^{\circ} 46^{\prime}-37^{\circ} 14^{\prime} \mathrm{E}$ longitude and altitude that ranges from 1740 to 2660 m.a.s.l and consists of 10 percent dega, and 90 percent woinadega, agro ecologies. The main rainy season in Kersa area stretches from March to September and the area receives an average annual rainfall of 900-1300 $\mathrm{mm}$. Temperatures are moderate ranking from 20$28^{\circ} \mathrm{C}$ with variations across specific agro-ecologies. The dominant soil type in the experimental site was Nitisols. Acidity ranges from medium to strong, and $\mathrm{pH}$ is generally less than 6 [16].

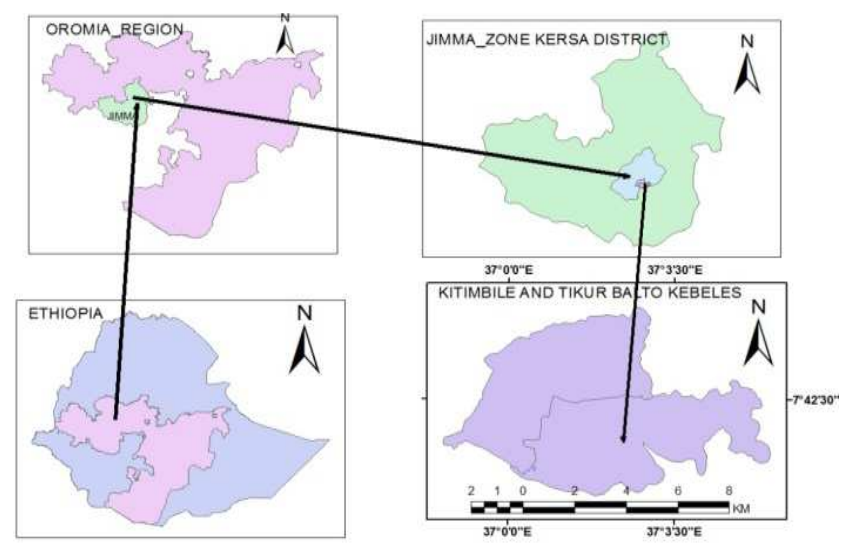

Figure 1. Map of the study area Kersa district-Jimma Zone, Oromia National Regional State.

\subsection{Experimental Design and Treatments}

The nutrient omission trials (NOTs) consisted of six treatments that included: the unfertilized control, PK $(0-40$ 40), NK (120-0-40), NP (120-40-0) NPK (120-40-40) in kg $\mathrm{ha}^{-1}$ and NPK + secondary nutrients such as sulphur (S), calcium $(\mathrm{Ca})$, magnesium $(\mathrm{Mg})+$ micro-nutrients such as boron (B) and zinc $(\mathrm{Zn})$, which here after is denoted as $\mathrm{NPK}+$. The rate of each nutrient in the $\mathrm{NPK}+$ treatment were 120-40-40-20-10-10-5-5 (kg ha $\left.{ }^{-1}\right)$ in that order. The experiment was conducted during main rainy season in 2017/18 at Kersa district. The treatments were laid out in a Randomized Complete Block Design. The experiment was established on six selected farmers' fields as replications. Choice of the experimental fields was limited to farmer fields currently in crop production. The plot size used was $4.5 \mathrm{~m} \mathrm{x}$ $4.2 \mathrm{~m}\left(18.9 \mathrm{~m}^{2}\right)$.

\subsection{Land Preparation, Fertilizer Application and Planting}

The experimental fields were prepared using a local plow (maresha) according to farmers' conventional farming practices. The fields were ploughed two times to a depth of $15-20 \mathrm{~cm}$ and furrows were constructed by a hand-held hoe. 
Bako hybrid maize (BH-661) which is high yielder as compared to other improved maize varieties in the study area was used as a test crop. A plant spacing of $75 \mathrm{~cm}$ (inter-row) and $30 \mathrm{~cm}$ (intra-row) was used. Two seeds of maize were planted per hill and later thinned to one seedling ten days after emergence. Other appropriate agronomic management practice was followed uniformly across treatments and farmers fields. Urea, triple super phosphate (TSP), Murate of potash (MOP), hydrated forms magnesium sulphate (MgSO4), calcium sulphate (CaSO4), zinc sulphate ( $\mathrm{ZnSO} 4)$ and borax were used as fertilizer sources for $\mathrm{N}, \mathrm{P}, \mathrm{K}, \mathrm{Mg}, \mathrm{Ca}$, $\mathrm{Zn}$ and $\mathrm{B}$, respectively.

The nutrients were applied based on nutrient requirements to achieve the expected attainable yield without nutrient limitation in each field. Basal fertilizer was applied in the planting holes at sowing time. Half of urea, whole of TSP, Murate of Potash, Calcium Sulphate, Magnesium Sulphate, Zinc Sulphate and borax were spot applied in the planting holes at planting. The applied fertilizers were covered with some soil before placing the seeds to avoid direct contact of seed with fertilizer. Fertilizers were pre-weighed, using a suitable balance, for each plot before going to the field. The remaining half $(1 / 2)$ of urea was top dressed by spotapplication five weeks after emergence (35DAE) for all plots receiving $\mathrm{N}$. There were totally seven rows and 14 planting stations (maize) per row in the plot.

\subsection{Soil Sample Analysis}

Representative soil samples were collected from the experimental fields at the depth of $0-20 \mathrm{~cm}$ before planting, prepared and analyzed following standard laboratory procedures for some selected soil physico-chemical properties. The soil samples were analyzed for soil $\mathrm{pH}$, organic carbon, total nitrogen, available phosphorus, particle size and bulk density. Selected soil physical and chemical properties were analyzed at Jimma Agricultural Research Center, Soil and Plant Analysis Laboratory. Bulk density of the soil samples was analyzed on undisturbed soil samples collected using the core sampling method [17]. The $\mathrm{pH}$ of was measured using potentiometric method in 1:2.5 soil water suspensions [18]. Organic carbon content was determined by the wet oxidation method of Walkley and Black [19] and total nitrogen by the semi-micro Kjeldahl method [20]. Available soil P was determined using Bray-II method as described by [21]. The particle size distribution was determined by the hydrometer method [22]. Exchangeable acidity following extraction by $1 \mathrm{M}$ potassium chloride and titration of the extract against sodium hydroxide solution following the procedure described by [23].

\subsection{Crop Management}

The trials were researcher-designed and managed to ensure uniformity and optimal management. Uniformity in management was ensured and the following standard agronomic practices were followed. The plots were regularly weeded to minimize any impact of weed pressure on maize performance. Pest infestation and disease symptoms were monitored regularly and controlled appropriately.

\subsection{Agronomic Data Collection}

Relevant plant parameters were recorded from the five central rows $\left(12.6 \mathrm{~m}^{2}\right)$ out of the seven rows per plot $\left(14.6 \mathrm{~m}^{2}\right)$. Plant parameters measured include plant height, stem girth, ear height, leaf area, stand count, number of cobs per plot, weight of cobs per plot, weight of five sub-sample cobs for determination of shelling percentage, weight of grain yield, and stover yield.

The height $(\mathrm{cm})$ of five randomly selected plants per plot were measured from ground level to the point where the tassel started branching when $50 \%$ of the plants in the plot reached tasselling stage and the mean value was taken as plant height. Leaf area Index was determined from five randomly selected plants per plot with the method developed by [24]. Harvest index was calculated as the ratio of grain yield to above ground biomass yield on dry weight basis [25]. Grain and stover yields were determined by harvesting the entire net plot area of $\left(3 \mathrm{~m} \times 4.2 \mathrm{~m}=12.6 \mathrm{~m}^{2}\right)$ and converted into kilogram per hectare. The harvested grain yield was adjusted to $12.5 \%$ moisture level [26]. The adjusted seed yield at $12.5 \%$ moisture level per plot was converted to grain yield as kilogram per hectare; whereas stover yield was weighed after leaving it in open air for 7 days. The above ground total biomass yield was calculated as the sum of the grain and stover yields.

$$
A E=\frac{G Y f-G Y c}{\text { Fertilizer applied } \mathrm{kg} / \mathrm{ha}}
$$

\subsection{Harvesting and Determination of Grain and Biomass Yield}

Harvesting was done after the crop has reached physiological maturity and the cobs have dried through monitoring the grain moisture content. All the plants in the net-plot were cut at the soil surface and total stover fresh weights determined in the field. The cobs were then harvested in such a way that the husk still remain on the plant. The cobs were counted and the weight of the total number of cobs was determined. Grain and stover yields were determined by harvesting the entire net plot area of 5 rows $\times 4.2 \mathrm{~m}$ (leaving out 2 rows from each end) and converted into kilogram per hectare. Grain yield was adjusted to $12.5 \%$ moisture level; whereas stover yield was weighed after leaving it in open air for seven days. The total dry matter yield, grain yield (at $12.5 \%$ moisture content), and harvest index were calculated as a ratio of grain yield to total biological yield.

\subsection{Statistical Data Analysis}

The collected agronomic data were analyzed using statistical analysis software (SAS) 9.3 [27]. Analysis of variance (ANOVA) was carried out to determine whether there was a significant difference among treatments. Mean 
separation of significant treatments was carried out using the least significant difference (LSD) test at $\mathrm{P} \leq 0.05$ levels.
Correlation analysis was done to establish the relationship between yield and yield components.

\section{Results and Discussion}

Table 1. Selected physicochemical properties of soil before planting maize on farmer's field.

\begin{tabular}{|c|c|c|c|c|c|c|c|}
\hline Treatments & Farm-1 & Farm-2 & Farm-3 & Farm-4 & Farm-5 & Farm-6 & Mean \\
\hline Sand (\%) & 54.00 & 56.00 & 64.00 & 58.00 & 54.00 & 64.00 & 58.33 \\
\hline Silt (\%) & 12.00 & 10.00 & 12.00 & 20.00 & 24.00 & 6.000 & 14 \\
\hline Clay $(\%)$ & 34.00 & 34.00 & 24.00 & 22.00 & 22.00 & 30.00 & 27.67 \\
\hline Textural class & SCL & SCL & SCL & SCL & SCL & SCL & SCL \\
\hline $\mathrm{BD}\left(\mathrm{g} / \mathrm{cm}^{3}\right)$ & 1.060 & 1.020 & 1.160 & 1.170 & 1.120 & 1.020 & 1.09 \\
\hline $\mathrm{pH}\left(\mathrm{H}_{2} \mathrm{O}\right)$ & 4.990 & 4.890 & 4.540 & 4.770 & 5.100 & 5.140 & 4.91 \\
\hline $\mathrm{OC}(\%)$ & 2.180 & 1.995 & 2.293 & 2.500 & 1.595 & 1.687 & 2.04 \\
\hline Av. P (mg/kg) & 0.957 & 0.878 & 2.761 & 3.388 & 3.545 & 7.251 & 3.13 \\
\hline $\mathrm{CEC}\left(\operatorname{cmol}(+) \mathrm{kg}^{-1}\right.$ & 12.44 & 15.92 & 15.98 & 17.10 & 13.60 & 20.16 & 15.87 \\
\hline Ex. A (meq/100g) & 1.610 & 1.620 & 1.860 & 1.520 & 1.080 & 1.016 & 1.45 \\
\hline
\end{tabular}

$\mathrm{SCL}=$ Silt Clay Loam, $\mathrm{OC}=$ Organic Carbon, $\mathrm{BD}=$ Bulk Density, $\mathrm{CEC}=$ Cation Exchange Capacity

\subsection{Effect of Fertilizer Treatments on Different Growth Parameters}

\subsubsection{Plant Height}

Plant height of maize was significantly affected $(\mathrm{p}<0.05)$ by fertilizer treatments. Significantly the tallest plant $(296.5 \mathrm{~cm})$ was obtained with the application of NPK + and NPK $(285.5 \mathrm{~cm})$ treatments compared to all the other treatments, while significantly the shortest plant $(228.4 \mathrm{~cm})$ was recorded for the control treatment followed by N-omitted $(245.5 \mathrm{~cm})$ and $\mathrm{P}$ omitted $(266 \mathrm{~cm})$ treatments (Figure 2). The extent of plant height reduction due to nutrient omission was in the order of $\mathrm{N}$ omission $>\mathrm{P}$ omission $>\mathrm{K}$ omission. The increment in plant height might be due to increase in cell elongation and more vegetative growth attributed to the balanced application, especially of primary nutrients $\mathrm{N}, \mathrm{P}$ and $\mathrm{K}$. On the other hand, the shortest plant in unfertilized plots might have been due to insufficiency of indigenous nutrients supplied by the soil to support plant growth as a result of low soil fertility status of the farms. Supporting the result of the current study, [28] reported that plant growth and development is significantly retarded if soil nutrients are less than their critical value for a crop or not adequately balanced with other nutrient elements. Thus, our results indicated that balanced nutrient application has considerably enhanced the maize vegetative growth such as plant height compared to unbalanced counterpart.

The increase in plant height with the application of balanced NPK fertilizer could be due to their synergistic effects and the fact that $\mathrm{N}$ is considered as one of the major limiting nutrients in plant growth and adequate supply of it promotes the formation of chlorophyll which in turn resulted in higher photosynthetic activity, vigorous vegetative growth and taller plants. Phosphorus is required for shoot and root development where metabolism is high and cell division is rapid while $\mathrm{K}$ is required for stomata regulation and hence entry of raw materials of photosynthesis and water regulation [29]. Our results are in line with the findings of [30], who also reported significant difference in maize plant height in plots treated with balanced fertilizers compared to the unfertilized plots.

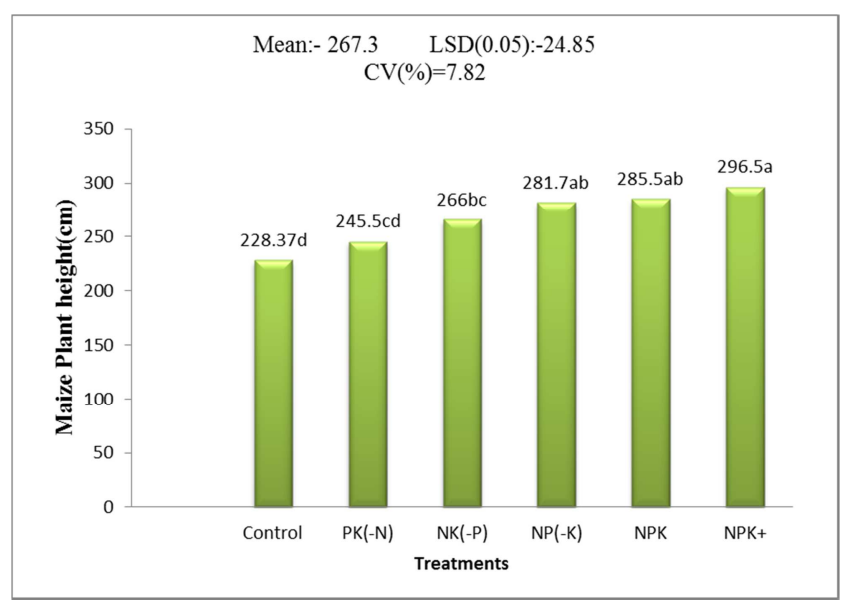

Figure 2. Effect of omitting different nutrients on maize plant height.

\subsubsection{Leaf Area Index}

Leaf Area Index of maize was significantly affected ( $\mathrm{P}$ $<0.05$ ) by fertilizer treatments (Figure 3). Significantly the highest leaf area index (3.92) was obtained with the application of balanced NPK and NPK+ (3.69) both of which were at par. The lowest LAI (2.15) and (2.48) were obtained from the control and $\mathrm{N}$-omitted treatments, respectively (Figure 3). The LAI increased by $63.3 \%$ due to application of NPK when compared to $\mathrm{N}$ omitted treatment and this increase was attributed to only $\mathrm{N}$ effect, while LAI increased by $76 \%$ due to NPK application compared to the P omitted treatment and the increase was solely due to $\mathrm{P}$ effect.

The leaf area index significantly increased with the application of balanced NPK fertilizer because of vigorous growth of the crop and leaf expansion in length and width. Leaf area index has primary importance in increasing the yield of crop. The reason for an increase of leaf area index could be attributed to development of more above ground biomass with expanded leaves produced in response to 
nitrogen. Phosphorous also promotes rapid canopy development and contributing to root cell division. Leaf expansion was improved in plants by giving chemical fertilizers and was illustrated in terms of leaf length and width. [1] Reported that growth of maize plants in terms of leaf area index varied significantly due to different nutrient applications. He reported the maximum leaf area index, from application of NPK as compared to the other treatments. Greater LAI in NPK treatment was attributed to production of new leaves and increase in size of the existing leaves [31].

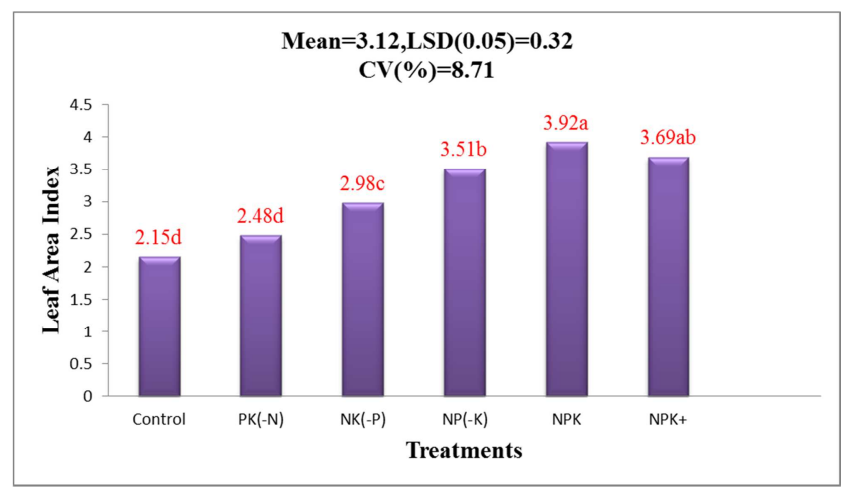

Figure 3. Effect of omitting different nutrients on maize Leaf area Index.

\subsection{Yield and Yield Components}

\subsubsection{Effect of Nutrient Omission on Maize Grain Yield}

The results of the nutrient omission trials showed that there was a significant fertilizer treatment effects on yields of maize (Figure 4). The highest maize grain yield $\left(9185 \mathrm{~kg} \mathrm{ha}^{-1}\right)$ was recorded with the NPK treatment followed by the NPK+ treatment $\left(8362 \mathrm{~kg} \mathrm{ha}^{-1}\right)$. Results demonstrated that addition of secondary and micronutrients did not increase maize grain yield. Our findings are agreement with the result [32] who also reported high maize yields with the application of NPK fertilizers as compared to NPK + demonstrating that secondary and micronutrients application does not increase grain yield in Jimma areas. The results indicate low grain yield was achieved for the treatment to which PK was applied (i.e. N omitted plot). This shows that $\mathrm{N}$ was the most grain yield limiting nutrient in this experiment. The absence of nitrogen before or at sowing results in highly reduced grain yield in maize. $\mathrm{N}$ application increased yield and yield components of maize. Many studies indicated that plants suffering from $\mathrm{N}$ deficiency mature earlier thus the vegetative growth stage is shortened leading to low grain yields. Further, [33] reported that adequate supply of nitrogen leads to a significant increase in grain yield and its components.

Following the control and PK treatments, the NK treatment where $\mathrm{P}$ was omitted gave lower grain yields. This observation was in line with the results of [34], who also found that the application of inadequate $\mathrm{P}$ depressed maize grain yield. [35] reported that plants require adequate $\mathrm{P}$ from the very early stages of growth for optimum production and this could be the reason why yield was depressed due to $P$ omission in the current study.[36]also reported depressed maize yields when $\mathrm{P}$ supply was inadequate over the entire maize growth period supporting our current observation. Enhanced early-season P nutrition in maize increased the dry matter partitioning to the grain at later development stages [37] and P omission will have the counterpart effect thus depressing grain yield as observed in the current study for $\mathrm{P}$ omitted treatment. There exists low biomass production of maize under $\mathrm{P}$ deficiency in field conditions since the aboveground biomass accumulation was severely reduced ($60 \%$ ) during early stages of maize growth [38]. Phosphorus deficiency results in plants that grow slowly with poorly developed root systems and small leaves of grayish-green color [38].

Nitrogen was the most grain yield limiting nutrient in the current study. However, both $\mathrm{P}$ and $\mathrm{K}$ omissions also significantly reduced the grain yield in all the maize farms $(p<0.05)$. Nitrogen had a major effect on growth and yield of maize. $\mathrm{P}$ was the next most important yield-limiting nutrient after $\mathrm{N}$ in the current study.

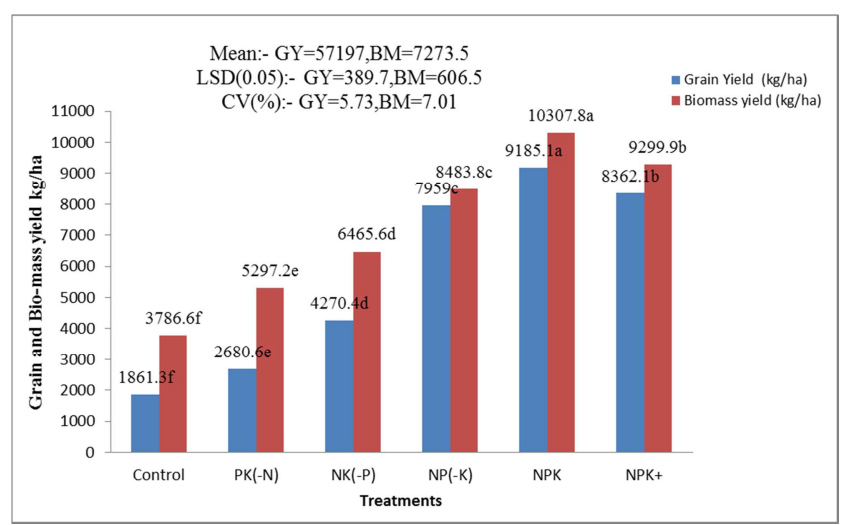

Figure 4. Effect of omitting different nutrients on maize grain yield and biomass yield.

Grain and biomass yield of maize were significantly affected $(\mathrm{P}<0.05)$ by the fertilizer treatments (Figure 4). Grain yield of maize significantly differed for all fertilizer treatments. Significantly the highest grain yield $\left(9185 \mathrm{~kg} \mathrm{ha}^{-}\right.$ $\left.{ }^{1}\right)$ was obtained with the application of NPK fertilizer compared to all the other treatments followed by the application of NPK $+\left(8362.1 \mathrm{~kg} \mathrm{ha}^{-1}\right)$, while the lowest grain yield was recorded for the control treatment $\left(1861.3 \mathrm{~kg} \mathrm{ha}^{-1}\right)$ and $\mathrm{N}$-omitted treatment $\left(2680.6 \mathrm{~kg} \mathrm{ha}^{-1}\right)$. The present result agrees with the finding of [32], who also observed the highest maize grain yield from the NPK treatments than the other treatments both in Bako Tibe and four districts of Jimma Zones. The fact that the highest maize grain yield was recorded for the NPK treated plots compared to the rests of the treatments has the implication that the current blended fertilizer should contain potassium both to enhance maize productivity as well as to safeguard further depletion of soil K. Other treatments, such as NP, NK and PK were lacking at least one major nutrient, i.e., $\mathrm{N}, \mathrm{P}$ or $\mathrm{K}$, and thus may induce a specific nutrient deficiency stress and retard overall growth of maize with a concomitant reduction in yield. Results showed that yield increase due to nitrogen application was $6504.5 \mathrm{~kg} \mathrm{ha}^{-1}$. Likewise, yield increase due to P application 
was $4914.7 \mathrm{~kg} \mathrm{ha}^{-1}$. The yield increase due to $\mathrm{K}$ application was only $1,226.1 \mathrm{~kg} \mathrm{ha}^{-1}$. The yield response to $\mathrm{K}$ fertilizer was much lower than to the crop response to $\mathrm{N}$ or $\mathrm{P}$ application, most likely due to high inherent soil $\mathrm{K}$ levels, which might be sufficient to satisfy the crop $\mathrm{K}$ demand. On the other hand, yield increase due to supplementing NPK with secondary and micronutrients was, $823 \mathrm{~kg} \mathrm{ha}^{-1}$. The result suggests that supplementing $\mathrm{N}$ and $\mathrm{P}$ fertilizers with $\mathrm{K}$ is more useful than supplementing with secondary and micronutrients, since there was no yield increase due to the later. There was no positive impact of secondary and micronutrient on maize grain yield in the study area. Therefore, application of fertilizer containing secondary and micronutrient is not an urgent matter at least in the current study. However, balanced application of $\mathrm{N}, \mathrm{P}$ and $\mathrm{K}$ fertilizers is quite important since such application significantly improved recovery efficiency. The highest grain yield in NPK treated plot could be due to highest final plant height $(285.5 \mathrm{~cm})$, leaf area index (3.92), and harvest index $(47.15 \%)$, respectively, suggesting that the improvement in the yield attributes might have increased the grain yield. This could be justified by the positive linear correlation between grain yield and plant height $(0.701 * *)$, and stem girth $(0.552 * *)$, and biomass yield $(0.992 * *)$ (Table 2$)$.

Further, the highest stover yield could also be another reason for the highest yield of maize under NPK fertilization plot. This has also been verified from the strong positive correlation between grain yield and stover yield $(0.962 * *)$ (Table 2). [39] also reported that application of balanced amount of nutrient increases nutrient uptake which facilitates more photosynthetic activity and more partitioning of dry matter to the ears, consequently increase in yield components and grain yield of maize. This forms the basis for high yield under high nutrient availability.

The lowest grain yield in PK (-N) and unfertilized control treatments indicate that $\mathrm{N}$ application cannot be substituted and has highest contribution in maize yield. It could be due to high effect of $\mathrm{N}$ on chlorophyll formation, photosynthesis and assimilate production because nitrogen stress reduces crop photosynthesis by reducing leaf area development and leaf photosynthesis rate by accelerating the leaf senescence [40]. Moreover, under $\mathrm{N}$ deficiencies, a considerably large proportion of dry matter is partitioned to roots than shoots, leading to reduced shoot/root dry weight ratio [41] and consequently the grain yield. Another strong reason might be due to low indigenous $\mathrm{N}$ supply capacity, as the soil of sloppy land is prone to soil and nutrient erosion.

Among the chemical fertilizers, nitrogen is also considered one of the most important factors affecting crop morphology, physiological traits and grain yield [42]. The main role of $\mathrm{N}$ in the plant is its presence in the structure of protein, the most important building substances from which the living material or protoplasm of every cell is made. In addition, nitrogen is also found in chlorophyll, the green colouring matter of leaves. Chlorophyll enables the plant to transfer energy from sunlight by photosynthesis. Therefore, the nitrogen supply to the plant will influence the amount of protein, protoplasm and chlorophyll formed. In turn, this influences cell size, leaf area and photosynthetic activity [43]. Maize is very sensitive to insufficient nitrogen and very responsive to nitrogen fertilization. Insufficient $\mathrm{N}$ availability to maize plants results in low yields and significantly reduced profits compared to a properly fertilized crop [44].

The nitrogen nutrient has synergistic effect on growth and yield attributes resulting in greater translocation of photosynthesis from source to sink, beneficial effect on physiological process, plant metabolism, growth and the major ingredient of proteins, enzymes, amino acids, amides and nucleic acids [45] and there by leading to higher grain yield. The $\mathrm{P}$ supply is particularly important for stimulating early root formation and growth, functions in plant macromolecular structures as a component of nucleic acids and phospholipids, with crucial roles in energy metabolism, participation in signal transduction path ways via phosphorylation and controlling key enzyme reactions [4]. Application of potassium fertilizer in adequate amount is essential for obtaining optimal crop yields. Many other researchers also have reported that the application of potassium fertilizer along with $\mathrm{N}$ and $\mathrm{P}$ fertilizers increased maize grain yield [46]. Generally, the application of balanced $\mathrm{N}, \mathrm{P}$ and $\mathrm{K}$ nutrient is useful to enhance crop productivity and nutrient use efficiencies.

\subsubsection{Biomass Yield}

Biomass yield was also significantly influenced by the fertilizer treatment $(p<0.05)$. The highest biomass yield was obtained with the application of NPK fertilizer, while the lowest biomass yield was obtained from the unfertilized control. N, P and $\mathrm{K}$ omission significantly reduced biomass yield over NPK application. The omission of N, P and $\mathrm{K}$ suppressed biomass yield (Figure 4). However, the biomass yield from the unfertilized control and $\mathrm{N}$ omitted treatments were significantly lower as compared to any of the other treatments (Figure 4). Biomass yield is strongly correlated with $\mathrm{K}$ supply and was reduced significantly due to its omission by $21.5 \%$ in comparison to NPK. Omission of secondary and micronutrients had no significant effect on biomass production.

\subsubsection{Harvest Index}

Harvest Index of maize was significantly affected $(\mathrm{p}<0.05)$ by the fertilizer treatments (Figure 5). The highest harvest index $(47.36 \%)$ was obtained by the application of NPK+ treatment compared to all the other treatments followed by the application of NPK (47.15\%), while the lowest harvest index was recorded from the control $(33 \%)$ and $\mathrm{N}$-omitted treatment $(34 \%)$.

On average, maximum leaf area index was observed when balanced NPK was applied. In addition to its effect in promoting photosynthetic activity, potassium increases cell expansion by regulating solute potential that may increase the rate of leaf expansion and the leaf area [47]. The treatments that promoted better growth of the maize crop had a positive influence on HI, presumably due to faster growth and partitioning of more carbohydrates into the grain. All 
treatments had higher HI compared to the control, reflecting poor plant growth in the control. The results suggest that an application of NPK supply is essential for optimized partitioning of dry matter between grain and other parts of the maize plant.

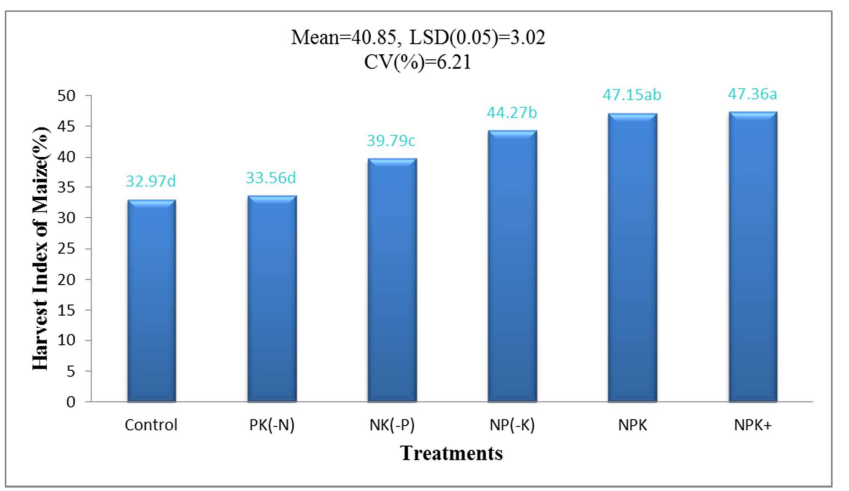

Figure 5. Effect of omitting different nutrients on maize harvest Index.

\subsection{Relationship Between Grain Yield and Yield Components of Maize}

All the independent variables showed a significant positive and linear relationship with grain yield (Table 2). The correlation analyses revealed that, there was a significant $(\mathrm{P}<$ 0.001 ) positive correlation between grain yield and yield related agronomic parameters of maize. Grain yield was significantly and positively correlated with biomass yield $(\mathrm{r}=$ $\left.0.962^{* *}\right)$, leaf area index $\left(\mathrm{r}=0.871^{* *}\right)$ and harvest index $(\mathrm{r}=$ $\left.0.931^{* *}\right)$. Biomass yield was positively correlated with almost all agronomic parameters of maize crop. This indicates increasing grain yield could increase yield components of maize and vise versa. This pattern agrees with the findings that most of the variation in grain yield could be explained by above-ground dry matter $[48,49]$. All these indicated that the improvement in above-ground plant biomass with maintenance of high harvest index could be of great benefit for an additional increase in maize grain yield. Similar findings were reported by [50] that grain yield of maize was positively and significantly correlated with yield components.

Table 2. Correlation among growth parameters, yield and yield components of Maize at Kersa.

\begin{tabular}{llllll}
\hline Variables & GY & BM & HI & PHT & LAI \\
\hline GY & 1.00 & $0.962 * *$ & $0.931 * *$ & $0.701 * *$ & $0.871 * *$ \\
BM & & 1.00 & $0.818^{* *}$ & $0.697 * *$ & $0.875 * *$ \\
HI & & & 1.00 & $0.651 *$ & $0.777 * *$ \\
PHT & & & & 1.00 & $0.873 * *$ \\
LAI & & & & & 1.00 \\
\hline
\end{tabular}

$\mathrm{GY}=$ Grain Yield; $\mathrm{BMY}=$ Biomass Yield; $\mathrm{HI}=$ Harvest Index; LAI=Leaf Area Index; $\mathrm{PH}=$ Plant Height; ** and * indicate significant at $\mathrm{P}<0.001$ and $\mathrm{P}<0.05$ level, respectively.

\subsection{Agronomic Efficiency of NPK Nutrients}

The agronomic efficiency of the nutrients was significantly influenced by the fertilizer treatments (Table 3). The results showed that the highest agronomic efficiencies of all N, P and $\mathrm{K}$ were observed for the NPK treatment followed by the $\mathrm{NPK}+$ treatments.

Table 3. Agronomic and Apparent Recovery efficiency of $N, P$ and $K$ as affected by nutrients.

\begin{tabular}{llll}
\hline \multirow{2}{*}{ Treatments } & \multicolumn{4}{c}{ Agronomic Efficiency (kg grain $\mathbf{~ k g}^{-1}$} & Nutrient applied) \\
\cline { 2 - 4 } & $\mathbf{A E}_{\mathbf{N}}$ & $\mathbf{A E}_{\mathbf{P}}$ & $\mathbf{A E}_{\mathbf{K}}$ \\
\hline Control & - & - & - \\
PK(-N) & - & $11.13 \mathrm{c}$ & $17.25 \mathrm{~d}$ \\
NK(-P) & $20.08 \mathrm{~d}$ & - & $50.02 \mathrm{c}$ \\
NP(-K) & $50.81 \mathrm{c}$ & $55.48 \mathrm{~b}$ & - \\
NPK & $61.03 \mathrm{a}$ & $68.81 \mathrm{a}$ & $152.58 \mathrm{a}$ \\
NPK+ & $54.17 \mathrm{~b}$ & $64.78 \mathrm{a}$ & $135.43 \mathrm{~b}$ \\
Mean & 46.52 & 50.05 & 88.83 \\
LSD $(0.05)$ & 2.74 & 6.36 & 6.76 \\
CV $(\%)$ & 4.78 & 10.32 & 6.18 \\
\hline
\end{tabular}

Agronomic Efficiency of N, P and K was significantly affected $(\mathrm{p}<0.05)$ by the fertilizer treatments (Table 3$)$. The $\mathrm{AE}_{\mathrm{N}}$ ranged from 20.08 (for $\mathrm{NK}$ treatment) to $61.03 \mathrm{~kg}$ grain $\mathrm{kg}^{-1}$ of applied $\mathrm{N}$ (for NPK treatment). The highest $\mathrm{AE}_{\mathrm{N}}$ was obtained from the application of NPK $(61.03 \mathrm{~kg}$ of grain kg ${ }^{1} \mathrm{~N}$ applied) treatment, while the lowest $\mathrm{AE}_{\mathrm{N}}$ was recorded from the application of $\mathrm{NK}(20.08 \mathrm{~kg} / \mathrm{kg})$. [51] Reported that the $\mathrm{AE}_{\mathrm{N}}$ for cereals in developing countries could reach $>30 \mathrm{~kg} / \mathrm{kg}$ under optimum crop management. The $\mathrm{AE}_{\mathrm{P}}$ ranged from 11.13 (for PK treatment) to 68.81 (for NPK treatment) $\mathrm{kg}$ of grain $\mathrm{kg}^{-1}$ applied P. Omission of $\mathrm{N}$ (i.e. PK treatment) extraordinarily reduced $A E_{P}$, suggesting that $P$ application in the absence of $\mathrm{N}$ cannot improve the agronomic efficiency of $\mathrm{P}$. The $\mathrm{AE}_{\mathrm{K}}$ ranged from 17.25 (for PK treatment) to 152.58 (for NPK treatment) kg of grain $\mathrm{kg}^{-1}$ $\mathrm{K}$. The highest $\mathrm{AE}_{\mathrm{K}}$ was obtained from the application of NPK (152.58 kg grain $\left.\mathrm{kg}^{-1} \mathrm{~K}\right)$ plot, while the lowest $\mathrm{AE}_{\mathrm{K}}$ was recorded from the treatment PK $\left(17.25 \mathrm{~kg}_{\text {grain }} \mathrm{kg}^{-1} \mathrm{~K}\right)$.

Obreza and Rhoads [52] also reported higher AE of N, P, and $\mathrm{K}$ with lower doses. The application of NPK fertilizers improved $\mathrm{N}$ use efficiency by about $200 \%$ as compared to NK treatment. Similarly, the same trend was observed with $\mathrm{P}$ and $\mathrm{K}$ use efficiencies. High agronomic efficiency would be obtained if the yield increment per unit applied is high [53]. A lower yield response to any of the nutrients indicates higher soil indigenous nutrient supply or higher soil fertility, resulting in lower agronomic efficiency. In contrast, a larger yield response means lower soil nutrient supply and relatively higher agronomic efficiency.

\section{Summary and Conclusion}

Higher mean grain yield of $9185.1 \mathrm{~kg} \mathrm{ha}^{-1}$ and biomass yields of $10307.8 \mathrm{~kg} \mathrm{ha}^{-1}$ maize were recorded with the application of balanced NPK fertilizers whereas the lowest was recorded from the control and $\mathrm{N}$-omitted treatments indicating that $\mathrm{N}$ was the most yield limiting nutrient for maize production than any other nutrient in the study areas. The yield response to $\mathrm{K}$ fertilizer was also not nil although it was lower compared to $\mathrm{N}$ or $\mathrm{P}$ fertilizers. However, yield did not increase due to application of secondary and micronutrients. Grain yield was strongly correlated with biomass yield $\left(\mathrm{r}=0.962^{* *}\right)$, leaf 
area index $\left(r=0.871^{* *}\right)$ and harvest index $\left(r=0.931^{* *}\right)$. The highest $\mathrm{AE}_{\mathrm{N}}$ was obtained from the application of NPK (61.03 $\mathrm{kg}$ of grain $\mathrm{kg}^{-1} \mathrm{~N}$ applied) treatment, while the lowest $\mathrm{AE}_{\mathrm{N}}$ was recorded from the application of NK $(20.08 \mathrm{~kg} / \mathrm{kg})$. The highest $\mathrm{AE}_{\mathrm{P}}$ was obtained from the application of NPK (68.81 $\mathrm{kg}$ grain $\mathrm{kg}^{-1}$ applied P) while the lowest AEP was recorded from the PK treatment (11.13 kg grain $\mathrm{kg}^{-1}$ applied $\mathrm{P}$ ). Omission of $\mathrm{N}$ (i.e. PK treatment) extraordinarily reduced $\mathrm{AE}_{\mathrm{P}}$, suggesting that $\mathrm{P}$ application in the absence of $\mathrm{N}$ cannot improve the agronomic efficiency of $\mathrm{P}$.

\section{Acknowledgements}

The first author gratefully acknowledges the Ethiopian Institute of Agricultural Research for granting leave of study and CIMMTY for the financial and logistic supports through the Taking Maize Agronomy to Scale in Africa (TAMASA) Project.

\section{References}

[1] Kumar, M., L. K. Baishaya, D. C. Ghosh, V. K. Gupta, S. K. Dubey, A. Das, and D. P. Patel, 2012. Productivity and soil health of potato (Solanum tuberosum L.) field as influenced by organic manures, inorganic fertilizers and bio fertilizers under high altitudes of eastern Himalayas. Journal of Agricultural Science, 4: 223.

[2] Neumann, K., P. H. Verburg, E. Stehfest and C. Müller, 2010. The yield gap of global grain production: A spatial analysis. Agricultural systems, 103: 316-326.

[3] Getachew Agegnehu, A. Ghizaw and W. Sinebo, 2006. Yield performance and land-use efficiency of barley and faba bean mixed cropping in Ethiopian highlands. European Journal of Agronomy, 25 (3), pp. 202-207.

[4] Marschner, P. and Z. Rengel, 2012. Nutrient availability in soils. In Marschner's Mineral Nutrition of Higher Plants (Third Edition) pp. 315-330.

[5] Getachew Agegnehu, Angaw Tsigie and Tesfaye Agajie, 2012. Evaluation of crop residue retention, compost and inorganic fertilizer application on barley productivity and soil chemical properties in the central Ethiopian highlands. Ethiopian Journal of Agricultural Sciences, 22: 45-61.

[6] Bogale Gelena, 2014. Resource and Nutrient Flows in Smallholders Farming Systems of Kumbursa Village, Ada'a district of Central Ethiopia. MA thesis paper presented for Addis Ababa University, Ethiopia, Addis Ababa.

[7] Asadu, C. L. A. and B. O. Unagwu, 2012. Effect of combined poultry manure and inorganic fertilizer on maize performance in an ultisol of Southeastern Nigeria. Niger. J. Soil Sci., 22: 79-87.

[8] Awotundun J. S., 2005. Comparative effects of organic and inorganic fertilizer on the yield of pop-corn. Proceedings of the 29th Annual Conference of the Soil Science Society of Nigeria, December 6-10, 2004, University of Agriculture Abeokuta, Nigeria.

[9] Stoorvogel, J. J., E. M. Smaling and B. H. Janssen, 1993. Calculating soil nutrient balances in Africa at different scales. Fertilizer research, 35 (3), pp. 227-235.
[10] Sanchez, P. A., K. D. Shepherd, M. J. Soule, F. M. Place, R. J. Buresh, A. M. N. Izac, A. U. Mokwunye, F. R. Kwesiga, C. G. Ndiritu and P. L. Woomer, 1997. Soil fertility replenishment in Africa: an investment in natural resource capital. Replenishing soil fertility in Africa, (replenishingsoi), pp. 1-46.

[11] Amujoyegbe, B. J., J. T. Opabode, and A. Olayinka, 2007. Effect of organic and inorganic fertilizer on yield and chlorophyll content of maize (Zea mays L.) and sorghum (Sorghum bicolor (L.) Moench). African Journal of Biotechnology, 6: 1869-1873.

[12] Nziguheba, G., R. Merckx and C. A. Palm, 2002a. Soil phosphorus dynamics and maize response to different rates of phosphorus fertilizer applied to an Acrisols in western

[13] Nziguheba, G., R. Merckx, C. A. Palm and P. Mutuo, 2002b. Combining Tithoniadiversifolia and fertilizers for maize production in a phosphorus deficient soil in Kenya. Agroforest. Syst. 55: 165-174. Kenya. Plant Soil 243: 1-10.

[14] Tilahun Amede and S. Schubert, 2003. Mechanisms of drought resistance in grain: II Stomatal regulation and root growth. SINET: Ethiopian Journal of Science, 26 (2), pp. 137-144.

[15] Kolawole, G. O., O. Eniola, B. Yetunde and Y. B. Oyeyiola, 2018. Effects of nutrients omission on maize growth and nutrient uptake in three dominant soil types of southwestern Nigeria. Journal of Plant Nutrition 41 (15): 1903-1915.

[16] Feyissa, A. and M. Mebrate, 1994. Provenance trial of Cordia Africana. In: Provenance trials of some exotic and indigenous tree species. Research Note No. 3, Forestry Research Centre, Addis Abeba: 81-96.

[17] Prikner, P., F. Lachnit, and F. Dvořák, 2014. A new soil core sampler for determination bulk density in soil profile. PLANT SOIL ENVIRON., 50 (6): 250-256.

[18] McLean, E. O. 1982. Soil $\mathrm{pH}$ and lime requirement: In: Methods of soil analysis part 2 (edited by AI Page; RH Miller and DR Keeney) Amer Soc of Agron Soil Sci Amer Inc. Madison, Wisconsin, pp. 191-224.

[19] Nelson, D. W. and L. E. Sommers, 1996. Total carbon, organic carbon, and organic matter. Methods of soil analysis part 3chemical methods, (methodsofsoilan3), pp. 961-1010.

[20] Okalebo, J. R., K. W. Gathua and P. L. Woomer, 1993. Laboratory methods of soil and plant analysis: a working manual. Tropical Soil Biology and Fertility Programme. Nairobi, Kenya.

[21] Bray R. H. and L. T. Kurtz, 1945. Determination of total organic and available forms of phosphorous in soils. Soil Science, 63: $370-379$.

[22] Gee, G. W. and J. W. Bauder, 1986. Particle-size analysis 1 (No. methods of soilan1, pp. 383-411). Soil Science Society of America, American Society of Agronomy.

[23] Okalebo, J. R., K. W. Gathua, and P. L. Woomer, 2002. Laboratory methods of plant and soil analysis: a working manual. TSBF-UNESCO, Nairobi, Kenya.

[24] McKee, G. W., 1964. A coefficient for computing leaf area in hybrid corn 1. Agronomy Journal, 56 (2), pp. 240-241.

[25] Donald, C. M. and J. Hamblin, 1976. The biological yield and harvest index of cereals as agronomic and plant breeding criteria. In Advances in agronomy, pp. 361-405. Academic Press. 
[26] Birru, A., 1979. Agricultural field experiment management manual part III. IAR (Institute of Agricultural Research). Addis Ababa, Ethiopia, pp. 35-42.

[27] SAS Institute Inc. 2012. SAS ${ }^{\circledR} 9.3$ Macro Language: Reference. Cary, NC: SAS Institute Inc. Stoorvogel, J. J., Smaling, E. M. A. 1993. Assessment of soil nutrient depletion in Sub-Saharan Africa: 1983-2000. TechnicalReport Winand Staring Centrum, Wageningen.

[28] Landon, J. R. 1991. Booker tropical soil manual: A Handbook for Soil Survey and Agricultural Land Evaluation in the Tropics and Subtropics. Longman Scientific and Technical, Essex, New York. 474p.

[29] Hasanuzzaman, M., M. H. M. Borhannuddin Bhuyan, Kamrun Nahar, Shahadat Hossain, Jubayer Al Mahmud. Shahadat Hossen, Abdul Awal Chowdhury Masud, Moumita and Masayuki Fujita. 2018. Potassium: A Vital Regulator of Plant Responses and Tolerance to Abiotic Stresses. Agronomy, 8 (31): 1-29.

[30] Adekayode, F. O. and M. O. Ogunkoya, 2010. Effect of quantity and placement distances of inorganic 15-15-15 fertilizer in improving soil fertility status and the performance and yield of maize in a tropical rain forest zone of Nigeria. J. Soil. Sci. Environ. Manage., 1: 155-163.

[31] Bandyopadhyay, K. K., A. K. Misra, P. K. Ghosh and K. M. Hati, 2010. Effect of integrated use of farmyard manure and chemical fertilizers on soil physical properties and productivity of soybean. Soil and Tillage Research, 110: 115-125.

[32] Tesfaye Balemi, Jairos Rurinda, Mesfin Kebede, James Muteji, Gebresilasie Hailu, Tolcha Tufa, Tolera Abera and Tesfaye Shiferaw, 2019. Maize Yield Response and Nutrient Use Efficiencies under Different Nutrients Application in Contrasting Agroecosystems. International Journal of Plant and Soil Sciences. 29 (3): 1-19.

[33] Alam, M. M., J. K. Ladha, Z. Rahman, S. R. Khan, A. H. Khan and R. J. Buresh, 2006. Nutrient management for increased productivity of rice-wheat cropping system in Bangladesh. Field crops research, 96 (2-3), pp. 374-386.

[34] Kogbe, J. O. S. and J. A. Adediran, 2003. Influence of nitrogen, phosphorus and potassium application on the yield of maize in the savanna zone of Nigeria. African journal of biotechnology, 2 (10), pp. 345-349.

[35] Grant C. A., D. N. Flaten, D. J. Tomasiewicz and S. C. Sheppard, 2001. The importance of earl season P nutrition. Can. J. Plant Sci. 81: 211-224.

[36] Bünemann, E. K., F. Steinebrunner, P.C. Smithson, E. Frossard, and A. Oberson, 2004. Phosphorus dynamics in a highly weathered soil as revealed by isotopic labeling techniques. Soil Science Society of America Journal, 68 (5), pp. $1645-1655$.

[37] Gavito, M. E. and M. H. Miller, 1998. Early phosphorus nutrition, mycorrhizae development, dry matter partitioning and yield of maize. Plant and soil, 199 (2), pp. 177-186.

[38] Plénet, D., S. Etchebest, A. Mollier and S. Pellerin, 2000.
Growth analysis of maize field crops under phosphorus deficiency. Plant and Soil, 223 (1-2), pp. 119-132.

[39] Lemcoff, J. H. and R. S. Loomis, 1986. Nitrogen influences on yield determination in maize 1. Crop Science, 26 (5), pp. 1017-1022.

[40] Rufty, T. W., S. C. Huber, and R. J. Volk, 1988. Alterations in leaf carbohydrate metabolism in response to nitrogen stress. Plant Physiology, 88 (3), pp. 725-730.

[41] Khan HZ, MA. Malik and MF. Saleem, 2008. Effect of rate and source of organic material on the production potential of spring maize (Zea mays L.). Pak J Agric Sci 45: 40-43.

[42] Bassi, D., M. Menossi, Mattiello and Lucia, 2018. Nitrogen supply influences photosynthesis establishment along the sugarcane leaf. Scientific Reports, 8: 2327 | DOI: 10.1038/s41598-018-20653-1.

[43] Zhang, Y., C. Li, Y. Wang, Y. Hu, P. Christie, J. Zhang and X. $\mathrm{Li}, 2016$. Maize yield and soil fertility with combined use of compost and inorganic fertilizers on a calcareous soil on the North China Plain. Soil and Tillage Research, 155, pp. 85-94.

[44] Yayock, J. Y., G. Lombin and J. J. Owonubi, 1988. Crop science and production in warm climates. Macmillan publishers.

[45] Fageria, N. K., V. C. Baligar and C. A. Jones, 2010. Growth and mineral nutrition of field crops. CRC Press.

[46] Yahiya, M., M. Samiullah, T. Khan and S. Hayat, 1996. Influence of potassium on growth and yield of pigeon pea (Cajanus Cajan). Indian Journal of Agronomy, 41: 416-419.

[47] Haefele, S. M., M. C. S. Wopereis, M. K. Ndiaye, S. E. Barro and M. O. Isselmou, 2003. Internal nutrient efficiencies, fertilizer recovery rates and indigenous nutrient supply of irrigated lowland rice in Sahelian West Africa. Field Crops Research, 80: 19-32.

[48] Katsura, K., S. Maeda, I. Lubis, T. Horie, W. Cao and T. Shiraiwa, 2008. The high yield of irrigated rice in Yunnan, China. Field Crops Research, 107: 1-11.

[49] Solomon, A., G. S. Yihenew, F. Getachew, and G. Birhanu, 2015. Time series trend analysis of temperature and rainfall in lake Tana Sub-basin, Ethiopia. Environ Syst Res, 4 (25), pp. $1-12$.

[50] Riar, A., D. Coventry, G. S. Bhullar, and N. K. Bhullar, 2012. Nitrogen use as a component of sustainable crop systems. Agricultural sustainability: Progress and prospects in crop research, pp. 63-76.

[51] Xu, X. P., P. He, M. F. Pampolino, A. M. Johnston, S. J. Qiu, and S. C. Zhao, 2014. Fertilizer recommendation for maize in China based on yield response and agronomic efficiency. Field Crops Res. 157: 27-34.

[52] Obreza, T. A. and F. M. Rhoads, 1988. Irrigated corn response to soil-test indices and fertilizer nitrogen, phosphorous, potassium, and magnesium. Soil Science Society of America Journal, 52: 701-706. 